\section{Classroom teachers' views on teacher-parent cooperation $^{1}$}

\section{Sınıf öğretmenlerinin öğretmen-veli işbirliğine ilişkin görüşleri}

\section{Sümeyye Bektaş ${ }^{2}$ \\ Ayşe Güler Küçükturan ${ }^{3}$}

Özet

Çalışmanın amacı öğretmen-veli işbirliğine ilişkin sinıf öğretmenlerinin görüşlerini ortaya koymaktır. $\mathrm{Bu}$ amaçla çalışmada durum çalışması kullanılmış ve Kocaeli ili Gebze ilçesi MEB'e bağlı bir ilkokuldaki on iki (12) öğretmenle çalışma gerçekleştirilmiştir. Veriler uzman görüşü alınarak araştırmacılar tarafindan hazırlanmış ve dört(4) açık uçlu sorudan oluşan yar1 yapılandırılmış bir görüşme formu aracilığıyla toplanmıştır. Verilerin analizinde betimsel analiz yöntemi kullanılmıştır. Veriler belli kategorilere göre gruplanmış, oluşturulan temalar ve alt temalara yerleştirilmiștir. Çalışma sonucunda öğretmenlerin öğretmen-veli işbirliğini sıklıkla kullandıkları ve öğretmenlerin bu işbirliğini veli toplantıları, whatsapp grupları, birebir görüşme ile sağladıkları görülmüştür. Öğretmenler öğretmen-veli işbirliğinin olumlu sonuçlar1 olarak sınıfin atmosferini olumlu yönde etkilediğini ve bu durumun da öğrenci başarısını artırdığını belirtmişlerdir,. Öğretmenveli işbirliğinin olumsuz sonuçları olarak ise velilerin öğretmenle aralarındaki mesafeyi koruyamadıkları ve öğretmene karşı samimi üslup kullandikları yer almıştır. Bunun sonucunda da öğretmenler sinıfta otorite kurmakta zorlandıklarını ve sinıfta verimli

\footnotetext{
${ }^{1}$ This article was presented as a paper at the International Classroom Teacher Symposium (USOS 2018) on 11-14 April.

2 Sakarya University, Institute of Education Sciences, Classroom Education, smyy.sau@, hotmail.com

3Prof. Dr., Sakarya University, Faculty of Educational, Department of Basic Education, gulerk@sakarya.edu.tr
} 
Bektaş, S., \& Küçükturan, A.G. (2020). Sınıf öğretmenlerinin öğretmen-veli işbirliğine ilişkin görüşleri. Journal of Human Sciences, 17(2), 521-534. doi:10.14687/jhs.v17i2.5981

teacher. As a result, the teachers stated that they had difficulty in establishing authority in the classroom and that they were not efficient in the classroom. In line with the results obtained from the study, suggestions were made for future studies and practitioners.

Keywords: Cooperation, communication teacher-parent, classroom teacher, family involvement, school-family relationships.

(Extended English summary is at the end of this document) olamadıklarını dile getirmişlerdir. Çalışmadan elde edilen sonuçlara uygun olarak ileride yürütülebilecek çalışmalar ve uygulayıcılar için önerilerde bulunulmuştur.

Anahtar Kelimeler: İşbirliğ̣i, iletişim, öğretmen-veli, sınıf öğretmeni, aile katılımı, okul-aile ilişkileri.

\section{Giriş}

Çocuğun eğitiminde ebeveynlerin ve öğretmenlerin önemi çok büyüktür. $\mathrm{Bu}$ nedenle öğrencilerin akademik ve sosyal performanslarını arttırmak için veli katılımının yolları aranır. Aktif veli katılımı, öğrencilerin akademik başarılarını, sosyal yeterliliklerini olumlu yönde etkiler; öğrenme performansında ve gelecekteki başarılarında önemli bir rol oynar (Ho, Hung, ve Chen, 2013; Chen, Yu ve Chang, 2007; Aslanargun, 2007).

Velinin eğitime katılımı, okul ve ev arasındaki devamlılı̆̆ da sağlayarak kazanılan bilgi ve becerilerin pekiştirilmesinde ve eğitimde sürekliliğin sağlanması sonucu başarının artmasında etkilidir (MEB,2013). Bu nedenle öğretmenlerin, veliler ile sık ve çeşitli yöntemlerle iletişim kurması beklenir. Velilerin öğretmenler ile karşılıklı güvene dayalı olarak iletişim kurmaları öğrenci başarısını arttırmanın yanında ortaya çıkan sorunları ve anlaşmazlıkları da azaltmada önemli bir rol oynar (Lueder, 1998). Bu bağlamda veli-okul iletişimi, fikir birliği geliştirmek, eylemi koordine etmek, paydaş ihtiyaçlarını yerine getirmek ve etkili öğrenme hedeflerine ulaşmak için bilgi alışverişinde bulunulan bir süreçtir (Ho, Hung, ve Chen, 2013).

Eğitim ve öğretim yalnızca okula ait değildir ve veliden bağımsız olarak düşünülmemelidir. Çalışmaların birçoğu, veliler ve öğretmenler arasındaki etkili iletişimin öğrenmeyi olumlu yönde etkilediğini göstermektedir (Çelenk 2003; Epstein, 2008; Michael, Dittus, ve Epstein, 2007; Angelides, Theophanous ve Leigh. 2006). Veliler ve öğretmenler öğretmen-veli işbirliğini çoğunlukla öğrenci başarısı üzerine kurmaktadır. Akbaba ve Samancı (2003) velilerin öğretmenle en çok öğrencinin başarı ve başarısızlık durumlarını görüştükleri (\%64), ardından da sınıf içi problemlerde (\%46) bir araya geldiklerini belirtmiştir. Ancak okul veli iletişiminin yalnız öğrenci başarısı üzerine kurulmaması, eğitim farklı boyutlarını da kapsaması gerekmektedir. Bu nedenle daha geniş bir kavram olan veli katılımı üzerinde durulmaktadır. Jeynes'e (2005) göre veli katılımı, velinin öğrencilerin eğitim deneyimlerine ve süreçlerine katılmasıdır. Bir başka deyişle veli katılımı, velilerin okul etkinliklerine gönüllü katılması, okulun sunduğu zorunlulukları yerine getirmesi, evde okuldaki öğrenmeyi destekleyici bir ortam hazırlaması, çocuğuna örnek olması, ev ödevlerini kontrol etmesi ve aktif olarak evde çocuğuna ders çalışmasına yardımcı olmasıdır (Cotton ve Wikelund, 1989). Başka bir tanıma göre ise veli katılımı, bir yanda velilerin görüşlerini düzenli olarak dikkate almak ve sunulan hizmetlere karşı tepkilerini değerlendirmek, diğer yandan ise velileri kendi çocuklarının eğitimi ve gelişiminde aktif birer işbirlikçi olarak görmek ve çocuklarının okul yaşantıları hakkında iyi bir şekilde bilgilendirilmelerini sağlamaktır (Jowett ve Baginsky, 1991).

Yapılan tanımlamalar veli katılımının farklı boyutları olduğunu göstermektedir. Epstein'e (1995) göre veli-okul arasındaki ilişkinin altı boyutunu vardır. Var olan altı boyut şöyledir: (a) veli görevleri (velilere çocukları için sağılk, bakım ve beslenme açısından iyi bir ortam sunarak destek olmak); (b) etkili iletişim (okul programları ve takibi ile ilgili etkili iletişimi sağlamak); (c) gönüllü olmak 
Bektaş, S., \& Küçükturan, A.G. (2020). Sınıf öğretmenlerinin öğretmen-veli işbirliğine ilişkin görüşleri. Journal of Human Sciences, 17(2), 521-534. doi:10.14687/jhs.v17i2.5981

(okul hedeflerini ve çocuk gelişimini desteklemek için velilerin gönüllü olarak sosyal katılımını sağlamak ve örgütlemek); (d) evde öğrenme (öğrencilere ödevlerinde yardımc1 olmak için velileri bilgilendirmek); (e) karar verme (okul kararlarında velileri temsilcileri ile sürece dahil etmek); ve (f) toplum ile işbirliği (okul programlarını, veli uygulamalarını ve öğrenci gelişimini güçlendirmek için toplum kaynaklarından yararlanmak). Bu boyutlar iyi tanımlanmıştır ve veli davranışlarının karşılık gelen boyutlarını formüle etmek için faydalı kılavuzlar sağlar. Bununla birlikte, veliler tarafindan başlatılan katılımlar yerine öğretmen ve okul tarafından başlatılan davranışları ölçer.

Epstein(1995) velilerin eğitim sürecine katılması için farklı başlıklar oluşturmuş ve velilerin eğitime nasıl katılabileceklerine ait etkinlik ve içerik örnekleri sunmuştur.. Bu başlıklar;

- Çocuk bakımı: Velilere çocukları için en iyi ev ortamı, sağlık ve beslenme açısında iyi bir program sunmak ve velilere destek olmak.

- İletişim: Ev ile okul arasında doğru ve etkili iletişim yolları bulmak, velilere düzenli olarak çocukla ilgili raporlar göndermek, veli toplantıları yapmak.

- Gönüllülük: Okulda veliler için sosyal katılım sağlayacakları alanlar oluşturmak, etkinliklerin gönüllülük ilkesine uygun olarak gerçekleştirilmesini beklemek.

- Evde öğrenme: Evde öğrencilerin ödevlerinde velilerin neler yapmaları gerektiği nasıl yardımc1 olabilecekleri konusunda bilgilendirmek.

- Karar verme: Öğrenciler ile ilgili alınan kararlarda veliyi de sürece dahil etmek, okulla ilgili işlerde ilgili bir temsilci belirlemek ve diğer velilerin de bu temsilci ile iletişim kurabilmesini sağlamak.

- Toplumla İşbirliği: Toplumun sağlığı, sosyal hizmetleri, kültürü konularında velileri ve öğrencileri bilgilendirmek, bu tür etkinliklere veli ve öğrenci katılımını sağlamak (akt. Erdoğan ve Demirkasımoğlu, 2010).

Diğer taraftan okul ile veli arasındaki iletişim eksikliğinin, veli katılımının önünde engel teşkil ettiği ifade edilmektedir. Okul ile veli arasındaki etkileşim eksikliğişu şekilde sıralanmaktadır (Walberg, 2004; akt. Şahin ve Ünver 2005).

- Velilerin okul etkinliklerine katılmasının beklenmediğine ilişkin görüş,

- Okul etkinliklerine katılımın nasıl sağlanacağının veliler tarafından bilinmemesi.

- Öğretmenlerin veli katılım etkinlikleri hakkında çok fazla bilgilerinin olmaması, bu tür katılımları planlamanın zaman alacağını düşünmeleri.

- Öğretmenlerin velilerin çok fazla etkinliklere yanaşmayacağını düşünmeleri ve katılsalar bile sınır tanımayıp bazı problem oluşturabileceklerine inanmaları.

Aslanargun (2007), okul veli işbirliğinin istenilen nitelikte gerçekleşmemesinin nedenlerini okulaile birliklerinin görevlerini doğru bir şekilde yerine getirmemeleri, veli ve yöneticilerin okul kayıt sırası ve bazı özel günler dışında çok fazla bir arada bulunamamaları ve okul aile birliği toplantılarında yeteri kadar katılımın sağlanmaması olarak siralamaktadır.

Dönmez ve Yıldırım (2008) ise ilkokulda velilerin yeterince okula uğramadıklarını, velilerin öğretmenlerin yalnızca para isteyecekleri kaygısını taşımaları ve bazı öğretmenlerin velilere karşı sert ve resmi tutum sergilemesinin öğretmen-veli işbirliğini sınırladıklarını dile getirmişlerdir.

Çocuğun gelişiminde ailesinin ve yakın çevrenin rolü büyüktür. Bu etkileşim doğumla başlamakta ve bireyin yaşamı boyunca devam etmektedir. Çocuk okul öncesi dönemle beraber eğitim öğretim faaliyetlerine başladığında bu süreçte bağımsız olacağı düşünülse de aile ve çevre çocukla beraber bu sorumluluğu paylaşmalıdır(Çıkar, 2019). Eğitim öğretim sürecinde veli katılımı yalnızca çocuk üzerinde etkili değildir. Veli desteğiyle başarı sağlayan çocuklar ileride topluma da yön vermekte ve bir çocuk tüm toplumu etkileyebilmektedir (Kıvrak, 2019). Veli katılımının öğrenci ve topluma olan katkıları göz önüne alındığında öğretmen-veli işbirliğinin önemi değer kazanmakta ve eğitim öğretim sürecinde öğretmen-veli iletişim kanallarının artırılması gerektiği anlaşılmaktadır. Bu bağlamda, bu çalışmanın amacı öğretmen-veli işbirliğinde kullanılan iletişim yollarını belirlenmek, ve 
Bektaş, S., \& Küçükturan, A.G. (2020). Sınıf öğretmenlerinin öğretmen-veli işbirliğine ilişkin görüşleri. Journal of Human Sciences, 17(2), 521-534. doi:10.14687/jhs.v17i2.5981

iletişimin hangi amaçla kurulduğunu ortaya koymak ve bulgular sşığında gelecekte yürütülecek çalışmalara yönelik önerilerde bulunmaktır.

\section{Yöntem}

Bu bölümde çalışma grubu, çalışmada kullanılan veri toplama aracı, verilerin toplanması ve analizine yer verilmektedir.

Bu çalısmada, nitel arastırma desenlerinden durum çalısması deseni kullanılmıstır. Durum çalışması, sistemli olarak bir durum ile ilgili kişi, sosyal ortam ya da olaya ait bilgi toplanarak durumun nasıl işlediğini ortaya koyan bir yöntemdir (Berg,1998). Yin’e (1994) göre, durum çalışması gerçek yaşam içinde bir olguyu betimlemek için "nasıl" ve "neden" soruları sorulduğunda kullanılır.

Diğer bir deyişle, "Durum çalışması; yeni var olan bir olguyu kendi gerçek yaşam çerçevesi içinde çalışan, olgu ve içinde bulunduğu içerik arasındaki sınırların kesin hatlarıyla belirgin olmadığ1 ve birden fazla kanıt veya veri kaynağının mevcut olduğu durumlarda kullanılan, görgül bir araştırma yöntemidir (Yin, 1984; akt. Yıldırım ve Şimşek, 2003, s.313).”

$\mathrm{Bu}$ çalışma durum çalışması desenlerinden biri olan bütüncül tek durum deseni ile yürütülmüştür. "Bütüncül tek durum deseni, tek bir analiz birimiyle (bir birey, bir program, bir okul v.b) yürütülen çalışmalardır (Yıldırım ve Şimşek, 2005, s.290)." Çalışmanın bir okul ve o okulun sınıf öğretmenleri ile sınırlı olması nedeni ile bütüncül tek durum deseni kullanılmıştır.

\section{1. Çalışma grubu}

Çalışma grubunun belirlemesinde, amaçlı örnekleme yöntemlerinden kolayda örnekleme yöntemi kullanılmıştır. "Kolayda örnekleme zaman, emek ve harcamalardan tasarruf edilmek istendiğinde, diğer örnekleme yöntemlerinin kullanılamaması durumunda erişilmesi kolay vakalar ele alındığında tercih edilen bir örnekleme yöntemidir (Patton, 1990, p.182-183; Yıldırım ve Şimşek, 2013, s.141)."

$\mathrm{Bu}$ nedenle çalışma grubunu Kocaeli ili Gebze ilçesi MEB'in bünyesinde bulunan bir ilkokulun sınıf öğretmenleri oluşturmaktadır. Çalışmanın yürütülebilmesi için okul yönetiminden izin alınmış ve 15 öğretmene ulaşılmıştır. Ancak çalışma 3 öğretmenin katılmak istememesi nedeniyle gönüllülük ilkesi çerçevesinde 12 öğretmen ile gerçekleşmiştir. "Nitel araştırmalarda olasılıklı örnekleme yapılmadan genellikle az sayıda kişiyle çalışıllır ve kesin sonuçlara varma ya da sonuçların topluma genellenmesi kaygısı güdülmez (Yıldırım ve Şimşek, 2013, s.48-65).” Öğretmenlerin 7'si kadın 5’i erkek olup gerçek isimleri kullanılmamıştır.

Tablo 1: Görüslerine basvurulan ögretmenlere iliskin bilgiler

\begin{tabular}{|c|c|c|}
\hline Kat1lımcilar & Cinsiyet & Hizmet Süresi \\
\hline 1. Y1lmaz Öğrt. & Erkek & 23 \\
\hline 2. Resul Öğrt. & Erkek & 32 \\
\hline 3. Ali Öğrt. & Erkek & 14 \\
\hline 4. Gökhan Öğrt. & Erkek & 12 \\
\hline 5. Oğuz Öğrt. & Erkek & 15 \\
\hline 6. Elif Öğrt. & Kadın & 19 \\
\hline 7. Yasemin Ö̈̆grt. & Kadın & 18 \\
\hline 8. Tuğba Öğrt. & Kadin & 13 \\
\hline 9. Ela Öğrt. & Kadın & 11 \\
\hline 10. Semra Öğrt. & Kadın & 10 \\
\hline 11. Pınar Öğrt. & Kadin & 4 \\
\hline 12. Eda Öğrtt. & Kadın & 1 \\
\hline
\end{tabular}


Bektaş, S., \& Küçükturan, A.G. (2020). Sınıf öğretmenlerinin öğretmen-veli işbirliğine ilişkin görüşleri. Journal of Human Sciences, 17(2), 521-534. doi:10.14687/jhs.v17i2.5981

\subsection{Verilerin Toplanmas1}

Verilerin toplanmasında kullanılacak formda yer alacak soruların oluşturulması sürecinde; okul yöneticilerinden (okul müdürü ve müdür yardımcısi) öğretmen veli iletişimi konusunda genel bir bilgi alınmış, konu ile ilgili literatür ve araştırmalar incelenmiş, iki alan uzmanının yapılacak çalışma ile ilgili görüşü alınmıştır. Öğretmen-veli işbirliğinin var olan durumunu ortaya koymak amacıyla dört açık uçlu sorudan oluşan görüşme formu oluşturulmuştur. Nitel yöntemlerde en sık kullanılanılan veri toplama yöntemi görüşmedir. "Görüşme, insanların bakış açılarını, öznel deneyimlerini, duygularını, değerlerini ve algılarını ortaya koymada kullanılan oldukça güçlü bir yöntemdir (Yıldırım ve Şimşek, 2013, s.40-41)."

Görüşme sorularının kolaylıkla anlaşılması ve çok boyutlu olmaması, yanıtlayıcıyı yönlendirici olmaması gibi ilkelere dikkat edilmiştir (Bogdan ve Biklen, 1992; akt. Yılmaz ve Altınkurt, 2011). Bu ilkeler çerçevesinde veriler;

1.Öğretmen-veli işbirliğini hangi iletişim yöntemlerini kullanarak sağlıyorsunuz?

2.Öğretmen-veli işbirliğini hangi dersler için sağliyorsunuz?

3.Öğretmen-veli işbirliğinin olumlu yönleri nelerdir?

4.Öğretmen-veli işbirliğinin olumsuz yönleri nelerdir? soruları ile toplanmıştır.

\subsection{Verilerin Analizi}

Verilerin analizinde betimsel analiz yöntemi kullanılmıştır. "Betimsel analiz, elde edilen verilerin daha önceden belirlenen temalara göre özetlenip yorumlanması yaklaşımıdır. Doğrudan alıntılara sık sık yer verildiği bu yaklaşımda görüşülen ya da gözlenen bireylerin görüşleri çarpıcı bir şekilde yansitllır. $\mathrm{Bu}$ tür analizde amaç, elde edilen bulguları düzenlenmiş ve yorumlanmış bir biçimde okuyucuya sunmaktır (Yıldırım ve Şimşek, 2013, s.148)."

$\mathrm{Bu}$ bağlamda görüşme formundan elde edilen veriler ortak ya da benzer özellikler doğrultusunda kategoriler altında değerlendirilmiş \% ve frekansları verilmiş, alıntılarla desteklenmiştir.

\section{Bulgular}

Çalışma grubunda yer alan öğretmelerin sorulara verdikleri yanıtlar tablolar halinde aşağıda gösterilmiştir.

\section{1. Ö}

Öğretmenlerin öğretmen-veli işbirliğini sağlama yöntemlerine ilişkin verdikleri yanıtlar Tablo 2'de gösterilmiştir.

Tablo 2: Öğretmen-veli iletişim yöntemleri

\begin{tabular}{lcc}
\hline & Frekans & Yüzde \\
\hline Veli Toplantıları & 8 & $\% 66$ \\
Whatsapp Grupları & 6 & $\% 50$ \\
Birebir Görüşmeler & 6 & $\% 50$ \\
Telefon Görüssmeleri & 5 & $\% 41$ \\
Ev Ziyaretleri & 2 & $\% 16$ \\
Sinıf Annesi ile İletişim & 2 & $\% 16$ \\
Sevgi, Sayg1 & 1 & $\% 8$ \\
\hline
\end{tabular}


Bektaş, S., \& Küçükturan, A.G. (2020). Sınıf öğretmenlerinin öğretmen-veli işbirliğine ilişkin görüşleri. Journal of Human Sciences, 17(2), 521-534. doi:10.14687/jhs.v17i2.5981

Tablo 2'de, çalışmaya katılan öğretmenlerin, öğretmen-veli işbirliğinde kullandıkları yöntemler yer almaktadır. Buna göre öğretmenlerin veli iletişiminde çoğunlukla "veli toplantılarını (\%66)" kullandıklarını belirtmişlerdir. Veli toplantıları öğretmen, veli ve öğrencinin iletişim içinde oldukları zamanlardır (Çilkız, 2012). Öğretmen süreç ile ilgili bilgilendirme, öğrencilere ve velilere rehber olabilme, sınıfta ya da okuldaki gelişmelerle ilgili haberdar etme imkânı sağlayan yılda en az iki kere yapılan toplantılardır. Öğretmen ihtiyaç duyduğu takdirde daha fazla sayıda toplantılar da gerçekleştirebilir (Köse, 2018). "Veli toplantıları; velilerin temsil etme, eğitim konusundaki düşüncelerini ifade etme, karar verme sürecine katılma, danışılma gibi beklentilerini karşılaması açısından önemlidir (Sarıtaş, 2004, s.218)." Veli toplantılarının ardından "whatsapp grupları ve birebir görüşmeler (\%50)" öğretmen-veli işbirliğini sağlamada sıkça kullanılan yöntemler arasında yer almıştır. Öğretmenlerden bazılarının veli toplantıları ve whatsapp grupları hakkındaki düşünceleri şöyledir:

"Öğgretmen-veli işbirliğini en faz̧la telefon yoluyla sağhyorum. Bunu da konuşarak değil whatsapp yazısmalaryla sağlyyorum.”, (3. Ögretmen)

"Gerek toplantı gerekse birebir görüsme yaparak ve elbette whatsapp grubu sayesinde güncel konular paylastyorum.", (4. Ögretmen) (9. Ögretmen)

"Belirli arahklarla yapılan veli toplantılan ve olusturulan whatsapp gruplaryla veli iş birliğini sağhlyorum."

Öğretmenlerin verdikleri diğer cevapları incelediğimizde bu işbirliğini sağlamada sırasıyla "telefon görüşmeleri (\%41), ev ziyaretleri (\%16), sınıf annesi ile iletişime geçme (\%16) ve sevgi sayg1 (\%8)" temaları yer almıştır.

\section{2. Öğretmen-veli işbirliğinin sağlandığı derslere ilişkin görüşler}

Öğretmenlerin öğretmen-veli işbirliğini kullandıkları derslere ilişkin verdikleri yanıtlar Tablo 3’te gösterilmiştir.

Tablo 3: Öğretmen-veli işbirliğinin sağlandiğı dersler

\begin{tabular}{|c|c|c|c|c|c|c|c|c|c|}
\hline & $\begin{array}{l}\text { Hayat } \\
\text { Bilgisi }\end{array}$ & Türkçe & $\begin{array}{l}\text { Mate- } \\
\text { matik }\end{array}$ & $\begin{array}{c}\text { Fen } \\
\text { Bilimleri }\end{array}$ & $\begin{array}{l}\text { Sosyal } \\
\text { Bilgiler }\end{array}$ & $\begin{array}{l}\text { Görsel } \\
\text { Sanatlar }\end{array}$ & $\begin{array}{c}\text { Oyun } \\
\text { ve } \\
\text { FE }\end{array}$ & $\begin{array}{c}\text { Din } \\
\text { Kültürüu }\end{array}$ & Müzik \\
\hline Y1lmaz Öğrt. & $\checkmark$ & $\checkmark$ & $\checkmark$ & & & $\checkmark$ & $\checkmark$ & & \\
\hline Resul Öğrt. & $\checkmark$ & $\checkmark$ & & & & & $\checkmark$ & & $\checkmark$ \\
\hline Ali Öğrt. & $\checkmark$ & $\checkmark$ & $\checkmark$ & $\checkmark$ & & $\checkmark$ & $\checkmark$ & & \\
\hline Gökhan Öğrt. & $\checkmark$ & $\checkmark$ & $\checkmark$ & $\checkmark$ & & & & & \\
\hline Oğuz Öğrt. & & $\checkmark$ & $\checkmark$ & $\checkmark$ & $\checkmark$ & $\checkmark$ & & $\checkmark$ & \\
\hline Elif Öğrt. & & $\checkmark$ & $\checkmark$ & $\checkmark$ & & & & & \\
\hline Yasemin Öğrt. & $\checkmark$ & $\checkmark$ & $\checkmark$ & & & $\checkmark$ & & & \\
\hline Tuğba Öğrt. & $\checkmark$ & $\checkmark$ & $\checkmark$ & & & & & & \\
\hline $\begin{array}{l}\text { Semra Öğrtt. } \\
\text { Ela Öğrt. }\end{array}$ & & & $\checkmark$ & $\checkmark$ & $\checkmark$ & & $\checkmark$ & & \\
\hline Pınar Öğrt. & $\checkmark$ & $\checkmark$ & $\checkmark$ & $\checkmark$ & & & $\checkmark$ & & \\
\hline Eda Öğrt. & $\checkmark$ & $\checkmark$ & $\checkmark$ & $\checkmark$ & & & & & \\
\hline Toplam & 8 & 10 & 10 & 6 & 2 & 4 & 5 & 1 & 1 \\
\hline
\end{tabular}

Öğretmenlerin, öğretmen-veli işbirliğini sağladıkları derslere ilişkin yanıtları Tablo 3’te görülmektedir. Tabloda yer alan sonuçlara göre öğretmenlerin velilerle en fazla işbirliği kurdukları derslerin Türkçe \%83 (10 öğretmen) ve Matematik\%83 (10 öğretmen) dersleri olduğu görülmüştür. Ardından bu işbirliğinin kullanıldığı dersler sırasıyla Hayat Bilgisi \% $\mathbf{6 6 , 6}$ (8 öğretmen), Fen Bilimleri \%50 (6 öğretmen), Oyun ve Fiziki Etkinlikler 41,6 (5 öğretmen), Görsel Sanatlar \%33 
Bektaş, S., \& Küçükturan, A.G. (2020). Sınıf öğretmenlerinin öğretmen-veli işbirliğine ilişkin görüşleri. Journal of Human Sciences, 17(2), 521-534. doi:10.14687/jhs.v17i2.5981

(4 öğretmen), Sosyal Bilgiler \%16,6 (2 öğretmen), Müzik \%8 (1 öğretmen) ve Din Kültürü ve Ahlak Bilgisi \%8 (1 öğretmen) dersleridir.

\section{3. Öğretmen-veli işbirliğinin olumlu yönlerine ilişkin görüşler}

Öğretmenlerin öğretmen-veli işbirliğinin olumlu yönlerine ilişkin görüşleri Tablo 4'te gösterilmiştir.

Tablo 4: Öğretmen-veli işbirliğinin olumlu yönlerini

\begin{tabular}{lcc}
\hline & Frekans & Yüzde \\
\hline İstenilen Hedefe Ulaşma-Başarı & 8 & $\% 66$ \\
Arkadaşlık İlişkileri-Doğru Davranış & 4 & $\% 33$ \\
Motivasyon & 2 & $\% 16$ \\
Güven & 2 & $\% 16$ \\
Zaman Kullanımı & 1 & $\% 8$ \\
Öğretmen Etkililiği & 1 & $\% 8$ \\
Materyal Temini & 1 & $\% 8$ \\
Sorumluluk & 1 & $\%$ \\
\hline
\end{tabular}

Öğretmen-veli işbirliğini sağlamanın olumlu yönlerinin neler olduğuna ilişkin bulgular Tablo 4'te gösterilmiştir. Buna göre öğretmenlerin verdikleri yanıtlar sonucunda bu işbirliğinin en fazla “öğrenciyi istenilen davranışa ulaştırması - öğrenci başarısını arttırma (\% 66)" olduğu görülmüştür. Başarı "kişinin yetenek ya da yetişmeye bağlı olarak gösterdiği ansal ya da eylemsel etkinliklerinin olumlu ürünü, bir işi istenilen biçimde bitirmek, elde etmek, istediğini bulmak." olarak tanımlanmaktadır (Türk Dil Kurumu (TDK), 2018). Başarı sınırı kişiden kişiye farklılık gösterebilmektedir. Örneğin; bir öğrenci için yüksek ortalamayla sınıf geçmek başarı iken, bir basketbolcu için basket atmak başarı sayılmaktadır. İkinci olarak bu işbirliğinin olumlu yönleri arasında "arkadaşlık ilişkileri-doğru davranış (\% 33)" yer almaktadır. Ayrıca öğretmen-veli işbirliğinin olumlu sonuçlarının sırasıyla "motivasyon(\%16), güven(\%16), zamanı doğru kullanma(\%8), öğretmen etkililiği $(\% 8)$, materyal temini( $\% 8)$, sorumluluk(\%8)” olduğu görülmektedir.

Öğretmenlerdenden bazıları bu işbirliğinin olumlu yönleri olarak şunları söylemektedir: Ögretmen)

"Veli desteği alan ögrenci derslerinde daba basarlh olwyor. Arkadaslar ile iliskileri daba iyi oluyor." (1.

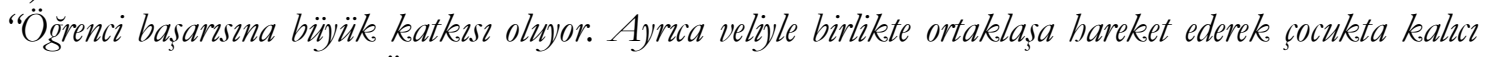
davransslar gelistirebiliyorum.” (7. Ögretmen)

"Ögrrencinin eğitim ve ögretiminde bütünlïk sağladı̆g için daha verimli çıtıılar alyyorum.” (12. Öğretmen)

\section{4. Öğretmen-veli işbirliğinin olumsuz yönlerine ilişkin görüşler}

Öğretmenlerin öğretmen-veli işbirliğinin olumsuz yönlerine ilisskin verdikleri yanıtlar Tablo 5’te gösterilmiştir. 
Bektaş, S., \& Küçükturan, A.G. (2020). Sınıf öğretmenlerinin öğretmen-veli işbirliğine ilişkin görüşleri. Journal of Human Sciences, 17(2), 521-534. doi:10.14687/jhs.v17i2.5981

Tablo 5: Öğretmen-veli işbirliğinin olumsuz yönleri

\begin{tabular}{lcc}
\hline & Frekans & Yüzde \\
\hline $\begin{array}{l}\text { Sınır Tanımama- Ö̆̆retmeni } \\
\text { Arkadaş Gibi Görme }\end{array}$ & 7 & $\% 58$ \\
Öğretmenin Sınıf & 4 & $\% 33$ \\
Hâkimiyetinde Zorlanması & & $\% 25$ \\
Velinin Duyarsız-İlgisiz Olması & 3 & $\% 16$ \\
Öğrencinin Olumsuz & 2 & \\
Davranışlar Sergilemesi & & \\
\hline
\end{tabular}

Öğretmenlerin, öğretmen-veli işbirliğinin olumsuz yönlerine ilişkin görüşleri Tablo 5’te verilmiştir. Öğretmenlerin veliler ile kurdukları iletişimde bazı zorluklarla karşılaştıkları, bu zorlukların sırasıyla "velilerin sınır tanımama ve öğretmenleri arkadaş gibi görme (\%58)", “öğretmenin sınıf hakimiyetinde zorlanması (\%33), velilerin duyarsız ve ilgisiz olmaları (\%25), öğrencinin olumsuz davranışlar sergilemesi(\%16)" olduğu görülmektedir. Öğretmenler, sağlanan işbirliğinde velilerin, öğretmen veli arasındaki sınırı koruyamadıklarını belirtmekte ve bundan olumsuz etkilendiklerini ifade etmektedirler.

Öğretmenlerdenden bazıları bu işbirliğinin olumsuz yönleri olarak şunları söylemektedir:

"Dikekatli olunmadiğnda ögretmen kontrolü kaybedebilir. Velinin ve ögrencinin ögretmeni yönlendirebilme bakekr olduğunu sanmasına neden olabilir. Veli ögretmenin özel hayatına girmeye çalısabilir.” (2. Öğretmen)

"Velilerin bazı durumlarda aradaki samimiyeti arturmak istemleri, velilerin yaptığ bazı ișlerde hesap sorar gibi konusmalar.” (5. Ögretmen)

"V elilerin sinm aşmalar, ögretmenin işine karısmaya çalısma, ögrencinin göəünde ögretmeni kü̈gük düsürme, ögrencinin sinf içince olumsuz davranıslar sergilemesi olumsuฉluklar arasmda sayllabilir.” (8. Ögretmen)

"Ë̆gr is birlĭginde denge săglanamąsa ögretmenin veliler üzerindeki hâkimiyeti azalir. Veliler dengeyi să̈layamadıklarnda kendilerini ögretmen ile arkadas gibi samimi görïyor, mesafeyi koruyamiyorlar.” (10. Öğretmen)

\section{Tartışma ve Sonuç}

Sınıf öğretmenlerinin, öğretmen-veli işbirliğine ilişkin görüşlerini incelemek amacıyla gerçekleştirilen bu çalışma, oniki (12) öğretmenle gerçekleştirilen bir durum çalışmasıdır. Öğretmenlerden dört (4) açık uçlu sorulara verdikleri yanttlar üzerinden toplanan veriler; öğretmenveli iletişim yöntemleri, öğretmen-veli işbirliğinin sağlandığ1 dersler, öğretmen-veli işbirliğinin olumlu yönleri, öğretmen-veli işbirliğinin olumsuz yönleri başlıkları altında incelenmiştir.

Öğretmenlerin, öğretmen-veli işbirliğini sağlamada en fazla kullandıkları yöntemin veli toplantıları olduğu tespit edilmiştir. Veli toplantıları öğretmenlerin \%66'sı tarafindan kullanılarak öğretmen-veli işbirliğini sağlamada en çok kullanılan yöntem olarak belirlenmiştir. Gökçe'nin (2000) yapmış olduğu araştırmaya göre yöneticilerin \%93’ü tarafindan işbirliğini sağlamada toplantıların önemli olduğu ileri sürülmüştür. Genç'e (2005) göre veli toplantıları ile öğretmenin düşüncelerini açıklaması sonucu öğrencilerde ödevlerini düzenli yapma, sınıf içi ve dışı ilişkilerde iyileşme ve düşüncelerini rahatllkla ifade etme gibi olumlu duygular gelişmiştir. Atakan'a (2010) göre ise öğretmenlerin büyük bir çoğunluğu veli toplantıları ve birebir görüşmeler ile iletişim kurduklarını dile getirmişlerdir. Yapılmış olan bu çalışmalar araştırma sonucunu destekler niteliktedir. Bu bulgu 10/7/2019 tarihli ve 30827 sayılı Resmi Gazetede yayımlanan Milli Eğitim Bakanlı̆̆1 Okul Öncesi Eğitim ve İlköğretim Kurumları Yönetmeliğinde yer alan her yarıyılda 1 kez olmak üzere yılda toplam en az 2 toplantı yapılması zorunluluğundan kaynaklanmaktadır. 
Bektaş, S., \& Küçükturan, A.G. (2020). Sınıf öğretmenlerinin öğretmen-veli işbirliğine ilişkin görüşleri. Journal of Human Sciences, 17(2), 521-534. doi:10.14687/jhs.v17i2.5981

Veli toplantılarının ardından öğretmen-veli işbirliği sağlamada öğretmenlerin en çok kullandığ1 yöntemler ise birebir görüşmeler ve whatsapp gruplarıdır. Birebir görüşme ve whatsapp grupları öğretmenlerin \%50'si tarafindan kullanılan yöntemler olarak belirlenmiştir. Çıkar’a (2009) göre de öğretmenler veli ile iletişimde kısa mesaj1 tercih etmekte, kısa mesajın yanı sıra yüz yüze görüşme ve whatsapp gruplarını kullanmaktadırlar. Yine Atakan (2010) öğretmen-veli işbirliğinde öğretmenlerin birebir görüşmeleri de sık kullandıklarını dile getirmiştir.

Öğretmenlerden, öğretmen-veli işbirliğini hangi dersler için sağladıklarını belirtmeleri istenmiş ve yanitlar listelenerek değerlendirilmiştir. Elde edilen sonuçlara göre ilk sırayı on(10) öğretmen ile Matematik ve Türkçe derslerinin aldığ1 görülmektedir. Ardından sekiz (8) öğretmen tarafindan Hayat Bilgisi dersi öğretmenlerin işbirliğini sağlamada en fazla kullandıkları ikinci ders olarak belirlenmiştir. Gültekin ve Kılıç'in (2014) öğretmen-veli işbirliğini kullanılmasının öğrencilerin Matematik, Türkçe, Fen ve Teknoloji, Sosyal Bilgiler derslerindeki performans notlarının artması ile pozitif bir ilişkinin olduğu sonucuna ulaşması bir yandan araştırma sonucunu desteklerken, diğer yandan bu derslerin iletişim sağlamadaki önceliğini de açıklar niteliktedir. Diğer taraftan Yurttaş Kumlu ve Çobanoğlu (2019) tarafindan yapılan araştırmada çalışmaya katılan veliler, Matematik dersinin çocukları için, Beden Eğitimi, Etik, Fen Bilimleri, Sanat, Sosyal Bilgiler, Türkçe ve Yabancı Dil derslerinden daha önemli olduğunu belirtmişlerdir. Kadlec, Friedman ve Ott (2007) ailelerin çocuklarının fen ile birlikte üst düzey matematik bilgisine sahip olmalarını, üniversite ve iş firsatları açısından bir kazanç olduğunu düşündüklerini belirtmişlerdir. Bu çalışmanın sonucuna göre öğretmenlerin Türkçe, Matematik, Hayat Bilgisi ve Fen Bilgisi derslerinin iletişim sağlamada öncelikli dersler olması ailelerin bu kaygılarından kaynaklandığı düşünülebilir.

Öğretmenlerin öğretmen-veli işbirliğinin olumlu yönlerine ilişkin görüşleri, bu işbirliğini sağlamadaki en önemli olumlu yönünün öğrencilerin istenilen hedefe ulaşması-başarı (\%66) olduğunu göstermiştir. Öğretmenlerin ya da velilerin işbirliğini sağlamadaki temel amacının öğrenci başarısına odaklanmalarıdır. Yapılan birçok çalışma, ailelerin çocuklarının akademik başarısını oldukça önemsediklerini (Burgess vd., 2014; Rubie-Davies vd., 2010; Schneider ve Buckley, 2002) ve öğretmen-veli işbirliğinin doğru kurulması sonucunda başarıyı da beraberinde getirdiğini göstermektedir. Dönmez ve Yıldırım'ın (2008) yaptıkları çalışma sonucunda bu işbirliğinin öğrencilerin başarısı üzerinde etkili olduğu sonucuna varılmıştır. Erdoğan ve Demirkasımoğlu (2010) ile Başaran ve Koç'un (2000) yaptıkları çalışmalar da öğretmen-veli işbirliğinin en fazla akademik çalışmalar/başarı odaklı olduğunu göstermiştir. Aynı şekilde öğretmen-veli işbirliğinin öğrencilerin akademik başarısını artırdığı, sosyal-duygusal gelişimini etkilediği ve davranış problemlerinde azalmaya katkı sağladığı yapılmış olan çalışmalarla da desteklenmektedir (Adams, Womack, Shatzer, Caldarella, 2010; Ashby, 2006; Epstein ve Sheldon, 2002; Hill ve Tyson, 2009; Kohl, Lengua ve McMahon, 2000). Öğretmen-veli işbirliğinin başarılı kurulması sonucunda öğrenci kendini güvende hissetmekte ve bu güven duygusu da öğrenciyi başarıya götürmektedir.

Öğretmen-veli işbirliğinin olumlu yönü olarak ikinci sırada öğretmenlerin \%33’ü tarafindan kabul gören arkadaşlık ilişkileri-doğru davranışa yönlendirme gelmektedir. Öğretmenler bu işbirliği sayesinde öğrencilere doğru davranışların neler olduğunu sezdirebilmekte ve öğrencinin arkadaşlık ilişkilerinde de etkili olmaktadır. Ö́ztürk’ün (2001) yapmış olduğu çalışmada da sınıfta oluşan olumsuzlukların ortadan kaldırılması için öğretmenlerin kullandığı yöntemler arasında veli ile iletişime geçme yer almaktadır.

Çalışmaya katılan öğretmenlerin öğretmen-veli işbirliğinin olumsuz yönlerine ilişkin görüşlerine göre, en olumsuz yönünün, öğretmenlerin \%58'i tarafindan belirtilen "velilerin sınır tanımamas1öğretmeni arkadaş gibi görmeleri” olduğu görülmektedir. Bu işbirliğinde sınırı koruyamayan veliler öğretmenlerin özel hayatlarına müdahale etmek istemekte ve kendilerini öğretmenler ile arkadaş gibi görmektedir. Bunun sonucunda öğretmenin otoritesi etkilenmekte ve öğretmen sinıf hâkimiyetinde zorlanmaktadır. Nitekim öğretmenlerin \%33’ü tarafindan da öğretmenlerin sınıf hakimiyetinde zorlanması en fazla karşılaşılan olumsuzluklar arasında gösterilmiştir. Öğretmen ile arasındaki sınırı koruyamayan velilerin öğrencileri sınıfta daha fazla istenmeyen davranış sergilemekte, özgürce 
Bektaş, S., \& Küçükturan, A.G. (2020). Sınıf öğretmenlerinin öğretmen-veli işbirliğine ilişkin görüşleri. Journal of Human Sciences, 17(2), 521-534. doi:10.14687/jhs.v17i2.5981

istediğini yapabileceğini düşünmekte ve öğretmenin otoritesini etkilemektedir. Paliç ve Keleş’in (2011) yapmış olduğu çalışmada sınıf yönetimdeki olumsuz davranışları ortadan kaldırmak için veli ile iletişime geçme bir öneri olarak verilmiştir.

Çalışmadan elde edilen bulgulara dayanılarak öğretmenler ve velilerin öğretmen-veli işbirliğini çoğunlukla veli toplantıları, yüz yüze görüşmeler ve whatsapp gruplarıyla sağladığı görülmektedir. Bu işbirliğinin öğrencilerin akademik başarısındaki artışta ve öğrencileri doğru davranışa yönlendirme de oldukça etkili bir yöntem olduğu sonucuna ulaşılmıştır. Bu işbirliğini sağlama sürecinde olumlu durumların yanı sıra olumsuz durumlar da meydana gelebilmektedir. Bu işbirliğini sağlama da oluşabilecek olumsuzluklar arasında velilerin mesafeleri koruyamadıkları dile getirilmiştir. Ancak öğretmen süreci doğru planlayarak oluşabilecek sorunları en aza indirebilir. Bu doğrultuda veliye ögrretmen ile arasındaki oluşabilecek sınır önceden bildirilmelidir. Veli hangi durum ve şartlarda öğretmene ulaşabileceği bilmeli ve öğretmenin özel hayatına müdahale etmesine engel olunmalıdır. Böylelikle veliler öğretmene karşı koruması gereken mesafeyi bilecek ve öğretmenin sinıf hâkimiyetinde veliden kaynaklı herhangi bir sorun oluşmayacaktır.

\section{Öneriler}

Öğretmen-veli işbirliğinin doğru kurulması için öğretmen ve yöneticilere bazı öneriler sunulabilir.

$\mathrm{Bu}$ işbirliğinin daha sağlam oluşması için öncelikle velilere kendilerinin değerli olduğu hissettirilmelidir. Bu amaçla sınıf ya da okulla ilgili alınan kararlarda veliler daha fazla sürece dâhil edilmeye çalışılmalıdır.

Velilerin okula karşı olumlu tutum geliştirmesi için okullarda velilere özel etkinlikler oluşturulmalı ve velilerin katılımı sağlanmalıdır.

Öğretmen sürecin başında veliyle olan mesafesini belirlemeli ve kimsenin özel hayatına müdahale etmesine izin vermemelidir. Bu amaçla öğretmenlere yönelik seminerler verilmelidir.

Yüz yüze toplantıya katılmada zaman engeli olan veliler için whatsapp grupları oluşturmak dışında da dijital kaynaklı yüz yüze görüşme olanaklarının kullanılması denenmelidir.

Velilere, öğrencinin yaşantısında başarısı için bütün derslerin önemli olduğu belirtilmeli ve öğrencinin özellikle sanat ve spor derslerine yönelik ilgi ve yetenekleri için ayrıca işbirliği yapmanın öğretmen ve velilere önemi belirtilmelidir.

Veli ile yapılacak toplantı ve görüşmeler dersler bazında ayrı ayrı olacak şekilde planlanarak her dersin önemi hissettirilmelidir.

Çalışma sonucunda yeni araştırmacılara öneri olarak etkili öğretmen özelliklerini inceleme, öğretmen-veli işbirliğini sağlamada kullanılacak alternatif yöntemleri tespit etme ve verimli öğretmenveli işbirliği nasıl olur konuları örnek araştırma konusu olarak sunulabilir.

\section{Kaynakça}

Adams, M. B., Womack, S. A., Shatzer, R.H., \& Caldarella, P. (2010). Parent involvement in school wide social skills instruction: perceptions of a home note program. Education, 130 (3), 513-28.

Akbaba, S. ve Samanc1, O. (2004). İlköğretimde veli-öğretmen görüşmelerinin değerlendirilmesi. XII. Eğitim Bilimleri Kongresi, Bildiriler, Ankara, 1, 1435-1440.

Angelides, P., Theophanous, L., \& Leigh, J. (2006). Understanding teacher-parent relationships for improving preprimary schools in Cyprus. Educational Review, 58(3), 303-316.

Ashby, N. (2006). Activity-filled family meeting leads to increases in parent involvement, student performance at Maryland school (Viers Mill Elementary School). The Achiever, 5(4), 1.

Aslanargun, E. (2007). Okul-aile işbirliği ve öğrenci başarısı üzerine bir tarama çalışması. Sosyal Bilimleri Dergisi, 18, 119-135. 
Bektaş, S., \& Küçükturan, A.G. (2020). Sınıf öğretmenlerinin öğretmen-veli işbirliğine ilişkin görüşleri. Journal of Human Sciences, 17(2), 521-534. doi:10.14687/jhs.v17i2.5981

Atakan, H. (2010). Okul öncesi eğitiminde aile katullmı çalssmalarmm ögretmen ve ebeveyn görüslerine göre değerlendirilmesi. Yayımlanmamış Yüksek Lisans Tezi. Çanakkale Onsekiz Mart Üniversitesi, Sosyal Bilimler Enstitüsü, Çanakkale.

Başaran, S. ve Koç, F. (2000). Ailenin çocuğun okuldaki eğitimine katılım sorunlar ve katılımın sağlanmasi için alternatif bir model. Ankara: Milli Ĕgitim Basımevi.

Berg, B. L. (1998). Qualitative Research Methods for the Social Sciences, Allyn and Bacon, Bostan.

Bogdan, R. C., \& Biklen, S. K.(1992). Qualitative research for education: An introduction to theory and methods.

Burgess, S., Greaves, E., Vignoles, A., \& Wilson, D. (2014). What parents want: School preferences and school choice. The Economic Journal, 125(587), 1262-1289.

Cotton, K. \& Karen Reed Wikelund, K.R. (1989). Parent involvement in education. Education Northwest, U.S. Department of Education.

Çelenk, S. (2003). Okul başarısının ön koşulu: okul aile dayanışması. İlkëğretim-Online, 2(2), 28-34, EDergi, bttp://ilkogretim-online.org.tr.

Ç1kar, İ. (2019). İlkokul ve ortaokul dïreyinde aile katıllmmmn veli görüsleri doğrultusunda incelenmesi: V an ili örneği (Yüksek Lisans Tezi). YÖK Tez Merkezi veri tabanından erişildi (Tez No: 581536).

Çilkız, S. (2012). Veli toplantıları. https://www.gundemturkiye.com/egitim/veli/velitoplantilari.html Erişim tarihi: 12.03.2020.

Dönmez, B ve Yıldırım, C. (2008). Okul ve aile işbirliğine ilişkin bir araştırma. Elektronik Sosyal Bilimler Dergisi, 23(7), 98-115.

Epstein, J. L. (1995). School/family/community partnerships: caring for the children we share. Phi Delta Kapan, 76(9).

Epstein, J. L., \& Sheldon, S. B. (2002). Present and accounted for: Improving student attendance through family and community involvement. The Journal of Educational Research, 95(5), 308-318.

Epstein, J. K. (2008). Improving family and community involvement in secondary schools. The Education Digest, 73(6), 9-12.

Erdoğan, Ç. ve Demirkasımoğlu, N. (2010). Ailelerin eğitim sürecine katılımına ilişkin öğretmen ve yönetici görüşleri. Kuram ve Uygulamada Eğitim Yönetimi, 16(3), 399-431.

Genç, S.Z. (2005). İlköğretim 1. Kademedeki okul-aile iş birliği ile ilgili öğretmen ve veli görüşleri. Türk. Ë̆itim Bilimleri Dergisi,3(2), 227-243.

Gökçe, E.(2000) ilköğretimde okul aile işbirliğinin geliştirilmesi. Pamukkale Üniversitesi Eğtim Fakültesi Dergisi, 7(7), 204-209.

Gültekin, M. ve Kilıç, Z. (2014). İlköğretimde çocuğu olan ailelerin çocuklarının eğitim ve öğretiminde karşılaştıkları sorunlar ve eğitim gereksinimleri. Türkiye Sosyal Araştırmalar Dergisi, 18(2), 85-111.

Hill, N. E. \& Tyson, D. F. (2009). Parental involvement in middle school: A meta- analytic assessment of the strategies that promote achievement. Developmental Psychology, 45(3), 740-763.

Ho, L. H., Hung, C. L., \& Chen, H. C. (2013). Using theoretical models to examine the acceptance behavior of mobile phone messaging to enhance parent-teacher interactions. Computers \& Education, 61, 105-114.

Jeynes, W.H. (2005). A meta-analysis of the relation of parental involvement to urban elementary school student academic achievement. Urban Education, 40(3), 237-69.

Jowett, S., \& Baginsky, M. (1991). Parents and education- issues, options and strategies. Educational Research, 33(3), 199-204.

Kadlec, A., Friedman, W., \& Ott, A. (2007). Important, but not for me: Parents and students in Kansas

and Missouri talk about math, science and technology education. https://files.eric.ed.gov/fulltext/ED498649.pdf . Erişim tarihi: 02.05.2020. 
Bektaş, S., \& Küçükturan, A.G. (2020). Sınıf öğretmenlerinin öğretmen-veli işbirliğine ilişkin görüşleri. Journal of Human Sciences, 17(2), 521-534. doi:10.14687/jhs.v17i2.5981

Kıvrak, Z. (2019). Öğretmenlerin gözünden ilkokul birinci sinif öğrencilerinin okuma yazฺma süreçlerine aile katiliminin etkisi (Yüksek Lisans Tezi). YÖK Tez Merkezi veri tabanından erişildi. (Tez No: 599646).

Kohl, G., Lengua, L. J. \& Mcmahon R. J. (2000). Parent involvement in school conceptualizing multiple dimensions and their relations with family anddemographic risk factors. Journal of School Psychology, 38(6), 501-523.

Köse, M. (2018). Iyi bir veli toplantısı için 10 tavsiye (öğretmenler ve velilere). https://www.makaleler.com/iyi-bir-veli-toplantisi-icin-10-tavsiye Erişim tarihi: 17.01.2020.

Lueder, D.C. (1998). Creating Partnerships with Parents: An Educator's Guide. Technomic Publishing Company, Inc. Lancaster, PA, USA.

Milli Ĕ̆itim Bakanlı̆̆1 (2019) Okul Öncesi Eğitim ve İlköğretim Kurumları Yönetmeliği

Milli Eğitim Bakanlığı (2013). 0-36 Ay Çocuklar İçin Eğitim Programı ile Bütünleştirilmiş Aile Destek Eğitim Rehberi (EBADER).

http://tegm.meb.gov.tr/dosya/okuloncesi/0-36ebaderegitimcikitap.pdf Erişim tarihi: 07.12.2019.

Michael, S., Dittus, P., \& Epstein, J. (2007). Family and community involvement in schools: results from the school health policies and programs study 2006. Journal of School Health, 77, 567-587.

Öztürk, N. (2001). Sinf ögretmenlerinin istenmeyen ögrenci davranışlarma ilişkin görïsleri. Yayımlanmamış Yüksek Lisans Tezi, Hacettepe Üniversitesi Sosyal Bilimler Enstitüsü, Ankara.

Paliç, G., \& Keleş, E. (2011). Sınıf yönetimine ilişkin öğretmen görüşleri. Kuram ve Uygulamada Eğitim Yönetimi, 17(2), 199-220.

Patton, M. N. (1990). Qualitative Evaluation and Research Methods. SAGE Publications.

Rubie-Davies, C. M., Peterson, E., Irving, E., Widdowson, D., \& Dixon, R. (2010). Expectations of achievement: Student teacher and parent perceptions. Research in Education, 83(1), 36-53.

Sarıtaş, M. (2004). Öğretmen-veli görüssmelerinin yönetimi. M. Şişman, \& S. Turan (Eds.), Sinıf yönetimi. Ankara: Pegem.

Schneider, M., \& Buckley, J. (2002). What do parents want from schools? Evidence from the Internet. Educational Evaluation and Policy Analysis, 24(2), 133-144.

Şahin, F. T.ve Ünver, N. (2005). Okul öncesi eğitim programlarına aile katılımı. Kastamonu Eğgitim Dergisi, 13(1), 23-30.

TDK, (2018). Türk Dil Kurumu. https://sozluk.gov.tr/

Yıldırım, A. ve Şimşek, H. (2005). Sosyal bilimlerde nitel araștırma yöntemleri. Ankara: Seçkin Yayıncılık.

Yıldırım, A. Ve Şimşek, H. (2013). Sosyal bilimlerde nitel araștrma yöntemleri. Ankara: Seçkin Yayıncılık.

Yılmaz, K. ve Altınkurt, Y. (2011). Göreve Yeni Başlayan Özel Dershane Öğretmenlerinin Kurumlarındaki Çalışma Koşullarına İlişkin Görüşleri. Kuram ve Uygulamada Eğitim Bilimleri, 11 (2), 635-650.

Yin, R.K (1984) Case Study Research: Design and Methods. Sage Publications, Beverly Hills, California.

Yurttaş Kumlu, G., ve Çobanoğlu, R. (2019). Çocukların eğitiminde merkezi sınav başarısı ile ilgili dersler daha mı önemli? Aile görüşü ve ilişkili faktörler. Pamukkale Üniversitesi Eğitim Fakültesi Dergisi, doi: $10.9779 /$ pauefd.561551.

\section{Extended English Summary}

Parents and teachers are very important in the education of the child. For this reason, ways of family participation are sought to increase students' academic and social performance. Active parent involvement positively affects students' academic achievement and social competence; It plays an important role in learning performance and future successes (Ho, Hung, and Chen, 2013; Chen, Yu and Chang, 2007; Aslanargun, 2007). 
Bektaş, S., \& Küçükturan, A.G. (2020). Sınıf öğretmenlerinin öğretmen-veli işbirliğine ilişkin görüşleri. Journal of Human Sciences, 17(2), 521-534. doi:10.14687/jhs.v17i2.5981

Teachers are expected to communicate with parents frequently and in a variety of ways. Parents' communication with teachers based on mutual trust plays an important role in reducing student problems as well as increasing student success (Lueder, 1998). In this context, parentschool communication is a process for developing consensus, coordinating action, meeting stakeholder needs and exchanging information to achieve effective learning goals (Ho, Hung, \& Chen, 2013).

\section{Aim of the Study}

Considering the effects of family participation on the life and success of the child, the methods used by the teachers who are the people who will communicate and communicate with the family become important. For this reason, the purpose of this study is to determine how teachers cooperate with parents and the positive and negative aspects of the methods they use.

\section{Method}

Case study; is an empirical research method that works in a new existing case within its real life framework and is used when the boundaries between the case and its content are not clearly defined and there is more than one source of evidence or data available (Yin, 1984; act. Yildırmm and Şimşek, 2003, p.313).

This study was carried out with a holistic single state pattern, one of the case study patterns. The holistic single state pattern is the studies carried out with a single unit of analysis (an individual, a program, a school, etc.) (Yıldırım \& Şimşek, 2005, p. 290). As the study is limited to a school and that school's classroom teachers, a holistic single case pattern was used.

\section{Results}

The teachers who participated in the study stated that they mostly use "parent meetings $(66 \%) "$ as the method of providing teacher-parent cooperation. After the parent meetings, "Whatsapp groups and one-on-one interviews (50\%)" were among the methods they frequently use to provide teacher-parent cooperation. When we examine the other answers given by the teachers, the titles of "phone calls $(41 \%)$, home visits $(16 \%)$, contacting the class mother $(16 \%)$ and respect for love $(8 \%)$ " were included in this cooperation.

According to the responses given to the question of which teachers are establishing teacherparent collaboration, the lessons that the teachers cooperate most with the parents are ten (10) teachers in Turkish and ten (10) teachers in Mathematics. Then, the courses in which collaboration was used were eight (8) teachers of Life science, six (6) teachers of Science, five (5) teachers of Game and physical activities, four (4) teachers of Visual arts, two (2) teachers of Music, one (Music) 1) teacher and Religious Culture and Moral Knowledge are listed as one (1) teacher. When the responses given to the question of teachers, what are the positive aspects of teacherparent cooperation are analyzed, it is seen that this cooperation is the most "bringing the student to the desired behavior - increasing student success $(66 \%)$ ". Secondly, "friendship relations-correct behavior (33\%)" are among the positive aspects of this cooperation. Among the positive results of teacher-parent collaboration are "motivation $(16 \%)$, trust $(16 \%)$, using time correctly $(8 \%)$, teacher effectiveness (8\%), material supply ( $8 \%$ ), responsibility (8\%). " Can be counted.

When we examine the responses of the teachers to the question of what are the negative aspects of teacher-parent cooperation, the most important aspect of this cooperation is "parents do not know borders and see teachers as friends (58\%)". Among the negative aspects of this collaboration, respectively, are the difficulty of the teacher in classroom domination (33\%), parents' being insensitive and indifferent (25\%), and student's negative behaviors $(16 \%)$.

As a result, teacher-parent collaboration is a very effective method for students' academic success and directing students towards correct behavior. Education and training are not just of school and should not be considered independently of the family. Unfortunately, there will be 
negative situations to achieve this cooperation, but when teachers plan the process in accordance with these negativities, the problem will be minimized. The border that must comply with the guardian must be drawn and prevented from interfering with his private life. Parents should know in what conditions and conditions they can reach the teacher. In this way, the parents will have kept their limits against the teacher and there will be no problems in the classroom domination or effectiveness of the teacher.

\section{Suggestions}

Some suggestions can be offered to teachers and administrators for the establishment of teacher-parent cooperation.

In order for this cooperation to be more solid, the parents should first be made to feel that they are valuable. For this purpose, parents should be tried to be included in more processes in the decisions taken about class or school.

In order for parents to develop a positive attitude towards the school, special activities should be created for the parents and parents should be involved.

The teacher should determine the distance from the parent at the beginning of the process and should not allow anyone to interfere with his private life. For this purpose, seminars for teachers should be given.

In addition to creating whatsapp groups for parents who have a time disability in attending face-to-face meetings, the use of digital face-to-face interviews should be tried.

It should be noted to parents that all lessons are important for the success of the student in his life, and the importance of collaborating with the teachers and parents for the student's interests and abilities, especially for arts and sports lessons, should be stated.

Meetings and interviews with parents should be planned separately on the basis of lessons and each lesson should be made more important.

As a result of the study, it can be presented as a sample research subject to examine effective teacher characteristics as a suggestion for new researchers, to determine alternative methods to be used in providing teacher-parent cooperation, and how efficient teacher-parent cooperation will be. 